\title{
Exploring the Prospective Mathematics Teachers Computational Thinking in Solving Pattern Geometry Problem
}

\author{
Swasti Maharani' ${ }^{1}$, Zeni Fadlila Agustina ${ }^{2}$, Muhammad Noor Kholid ${ }^{3}$ \\ DOI : $10.35445 /$ alishlah.v13i3.1181
}

\begin{abstract}
Article Info
Abstract

Keywords:

Computational thinking

(CT);

Geometric pattern;

Conceptualknowledge;

Procedural knowledge;

Generalization

This research aims to describe the characteristic of mathematics prospective teacher's computational thinking (CT) in solving the geometric pattern problem. The subject consists of 6.5 preservice mathematics teachers in Universitas in Madiun. The instrument was used in this research are geometric pattern problem tests and interview guidelines. The result shows that are three types of mathematics prospective teachers in solving the problem. First, CT substantial, i.e. prospective mathematics teachers use the conceptual knowledge who collaborated with procedural knowledge exactly. They use mathematics iteration to find the pattern and express them to the general form easily. Second, CT Nominal, i.e. prospective mathematics teachers, use manual ways to solve the pattern problem. They count using numeric, not symbolic, of solving the pattern formed. They can understand the design but can't express it to the mathematics model. Third, CT procedural, i.e. mathematics prospective teacher using the procedural knowledge only, not an expert in concept, and following the steps who teaches from experience before. The recommendation for future research is to develop the research to find the other characters in other mathematics subjects, in other students, to develop thelearning models who can embody CT.
\end{abstract}

\begin{abstract}
Abstrak
Penelitian ini bertujuan untuk mendeskripsikan karakteristik computational thinking (CT) mahasiswa calon guru matematika dalam menyelesaikan masalah geometri berpola. Subjek penelitian adalah mahasiswa program studi

pendidikan matematika di salah satu Universitas di Madiun sebanyak 65 mahasiswa. Instrumen yang digunakan dalam penelitian ini adalah tes masalah geometri berpola dan pedoman wawancara. Hasil penelitian menunjukkan bahwa terdapat 3 tipe mahasiswa calon guru matematika dalam menyelesaikan masalah matematika. Pertama, tipe CT substansial yaitu mahasiswa calon guru matematika yang menyelesaikan masalah dengan menggunakan pengetahuan konseptual yang dipadukan dengan pengetahuan prosedural. Mereka cenderung menggunakan iterasi matematis dalam menemukan pola dan dengan mudah mengekspresikannya ke dalam sebuah bentuk umum. Kedua, tipe CT nominal yaitu mahasiswa yang dalam menyelesaikan masalah geometri berpola cenderung menghitung manual menggunakan bilangan-bilangan atau angka-angka (tidak menggunakan simbol) untuk menyelesaikan pola yang terbentuk. Mahasiswa tipe ini cenderung dapat memahami pola, namun tidak bisa mengekspresikannya ke
\end{abstract}

Kata kunci:

Computational thinking

$(C T)$;

Geometriberpola;

Pengetahuan

konseptual;

Pengetahuan

procedural;

Generalisasi

\footnotetext{
1 Un iv ersitas PGRI Ma diun, In donesia

Em ail: swasti.mathedu@unipma.ac.id

2 Universitas PGRI Ma diun, In donesia

Em ail: zeniagustin1@gmail.com

3 Universitas Muhammadiyah Surakarta, In donesia

Em ail: Muhammad.Kholid@ums.ac.id
} 
dalam bentuk model matematika. Ketiga, tipe CT prosedural, yaitu mahasiswa yang dalam menyelesaikan masalah geometri berpola cenderung menggunakan pengetahuan prosedural saja, tidak menguasai konsep, dan hanya mengikuti langkah-langkah yang diajarkan dari hasil belajarnya terdahulu. Rekomendasi untuk penelitian selanjutnya adalah dapat mengembangkan penelitian untuk menemukan karakteristik lain pada mata pelajaran matematika lainnya, pada siswa lain, untuk mengembangkan model pembelajaran yang dapat mewujudkan CT.

\section{INTRODUCTION}

Geometry problems are closely related to everyday life. Nasution (2017) stated that Geometry is an essential material in everyday life. Besides increasing logical thinking, it can also be used to solve a mathematical problem. Furthermore, Hendriana (2013) stated that Geometry is fundamental in the mathematics learning curricula. The student can analyze, compare, generalize, and sharpen cognitive skills like critical, investigation, illustration, and thinking skills (Sudarsono; Erdogan 2009). On the other hand, Geometry has a vital role in supporting calculus, vector, and improved problem solving (Sugiyono 2014).

Geometry problems that are still rarely studied are pattern geometry problems. Pattern geometry trains students to have high self-confidence, solve problems well, and reason and communicate mathematics well. (Bobango, 1993). Pattern geometry can teach students to solve problems and appreciate the geometry of the solar system, geological formations, crystals, and architectural works of art (Yuniarti, 2014). Furthermore, pattern Geometry can increase the mathematics argumentation of prospective mathematics teachers (Reflina, 2020). Imswatama \& Muhassanah (2016) dan Nurfalah \& Bernard (2020) finding the learning outcomes in pattern Geometry subject is not in line with expectations, and there are problems. One of the problems is a lack of understanding of mathematics concepts. Pasandaran \& Mufidah (2020) research shows that $85 \%$ of college students had read the concept only, and they weren't replicated on the problems. They read a formula and the example only without understanding the concept. Based on the research results, there is a need for further research on solving pattern geometry problems.

The students need to analyze the similarities in characteristics that appear to form patterns in solving pattern Geometry problems. The analysis carried out needs to break down complex problems into more straightforward ones, clearly using abstractions and generalizations, and the algorithms used must also be precise. So it can be said that pattern geometry problems are closely related to computational thinking (CT). It is by the opinion of Aziz (2021) that pattern geometry requires $\mathrm{CT}$ so that the formulation of the problem and the solution are found to be effective in solving the problem of opinion. CT can be a strategy or method in compiling steps to solve patterned geometry problems (Selby, 2013). Prospective mathematics teachers need to skilled CT in the success of geometry material (Masfingatin \& Maharani, 2019), especially the pattern geometry problems. The prospective mathematics teachers can use CT as a learning strategy or practice to perform their pattern geometry skills (Meha \& Bullu, 2021).

CT is for prospective mathematics teachers to improve critical thinking skills in mathematics learning (Kawuri, Budiharti, \& Fauzi, 2019). According to Ansori (2020), CT is important for increasing mathematical knowledge, digitizing, and shaping the characteristics of prospective mathematics teachers so that they have good self-confidence, are open-minded, and care about the environment. $\mathrm{CT}$ is a thinking process that formulates problems into simpler forms to easily solve them by algorithms (Wing, 2008, 2011). CT components consist of five components, including abstraction, generalization, decomposition, algorithmic, and debugging (Angeli et al., 2016). CT can be applied in various disciplines, especially mathematics. Complex math problems can be solved easily. One of them is the CT strategy. Someone who always does CT will tend to 
solve problems coherently and systematically and break down complex problems into simpler problems. Complex geometric problems also require CT in their solution.

Geometry problems require critical solutions, so prospective mathematics teacher students need CT to be able to prove geometric theorems well and be able to argue logically and critically in problem-solving (Sengupta, Dickes, \& Farris, 2018). Student CT needs to be researched to determine the problem solving used in solving geometry problems (Astuti, 2017). Pattern geometry is a geometric problem that has a relationship with other materials. The closest is algebra. Pattern geometry problems are complex and high-level problems that require critical and logical thinking in solving (Zhu, 2007), so it is necessary to further investigate how CT students are prospective mathematics teachers in solving pattern geometry problems.

\section{METHOD}

This study is a qualitative descriptive study that aims to analyze and describe the CT of prospective mathematics teachers in solving pattern geometry problems. The data of this research will analyze using qualitative techniques and will be presented with a descriptive conclusion. The subjects in this study were prospective mathematics teacher students at a university in Madiun. Future subjects are all students of the 7 th semester of the mathematics education study program at one of the Universities in Madiun, totalling 65 students. Of the 65 students who met the subject, there were 12 students. The procedure for selecting the subject is by giving a question instrument about pattern geometry to 65 students. Subject criteria are students who can solve problems and perform CT in the completion process. In this study, 12 students met the criteria as subjects. The answers of the 12 subjects were further analyzed, and an interview was conducted on the answers to reveal a more in-depth CT.

The instrument used in this research is the researcher himself as the main instrument. In addition, there are supporting instruments, namely patterned geometry question sheets and interview guidelines. The patterned geometry question sheet contains one geometric material question that is used to obtain data in the form of the subject's answers to be analyzed to find out which CT is revealed. This pattern geometry test was conducted at the beginning of the study. The test sheet has been validated by two mathematicians, namely lecturers of the mathematics education study program. Here's a pattern geometry test question.

It is known that 5 unit square is built from a small square with a size of 1 unit, as shown in Figure 1 below. How many squares are there in the picture? And if made a square with a length of 100 units. What is the total number of squares?

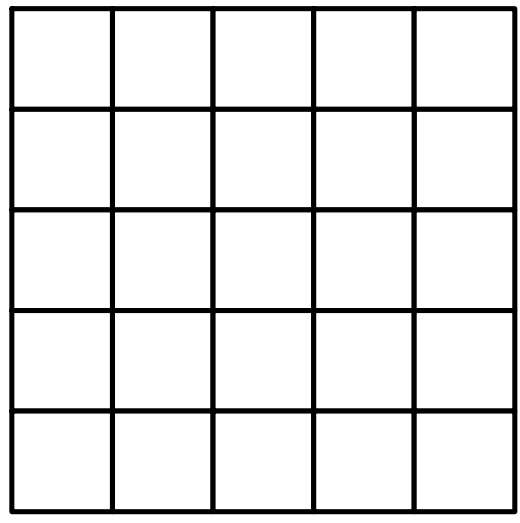

Figure 1. A 5 unit square

The following research instrument is the interview guide. The interview in this study is a semi-structured interview which refers to the subject's answers. Interviews were conducted to 
obtain interview data for reasons or narratives about the procedure for completing the issue and strengthen the subject's written responses. Interviews were born after the subjects were selected.

This research begins with the preparation of research instruments. Researchers compiled a patterned geometry test which was then validated by two validators, namely lecturers of the mathematics education study program. The researcher then collected a draft interview guide. Interview guidelines were prepared based on the CT components to be studied. After preparing the instrument, the researcher chose the subject by giving a patterned geometry test to all prospective issues, as many as 65 students. Of the 65 students, 12 students met as subjects. The topics in the interview related to the answers he wrote. As for more details, the research procedure can be seen in Diagram 1 below.

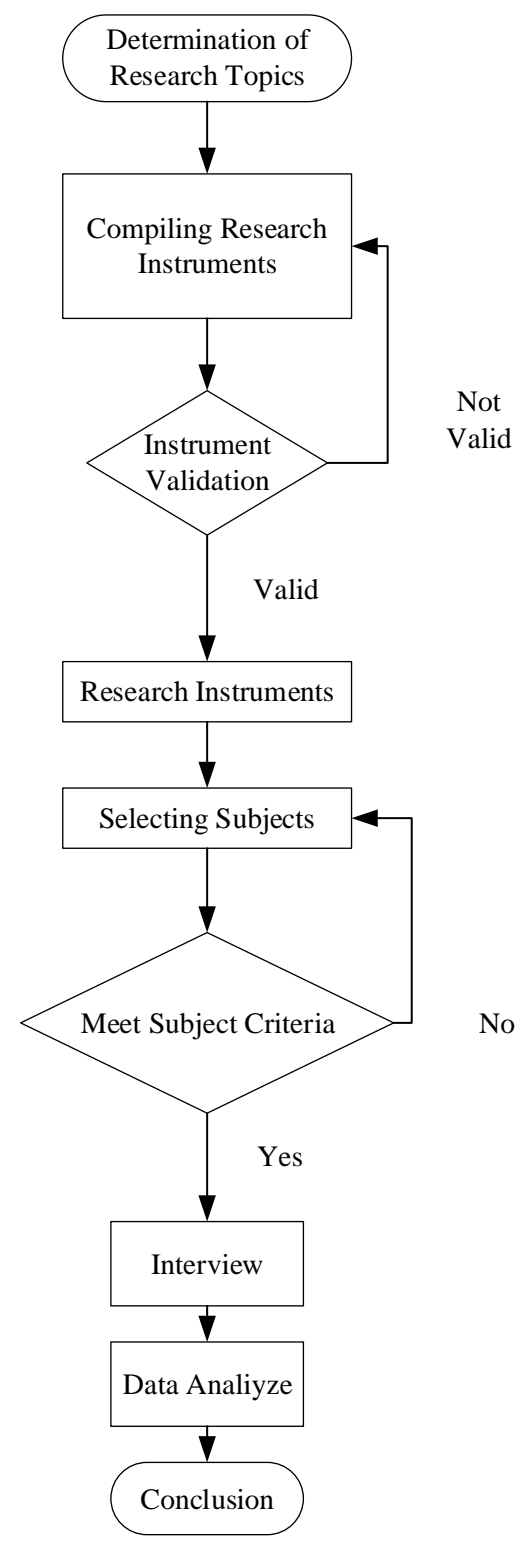

\section{Diagram 1. Research Procedure}

Data analysis techniques in this study include:

1. Data Reduction

Data reduction is the first step in identifying data by summarizing, summarizing, determining essential things according to the theme and pattern. This shows that data 
reduction is necessary for this study to produce data that is easy to understand or understand in carrying out research and further data collection.

2. Data Presentation

Data presentation is a step taken after reducing the data. Data presentation is presented in the form of a brief description. Data presentation regarding the results of this study is carried out by submitting data in the form of reports.

3. Conclusion

Drawing conclusions is the final step after reducing data and presenting data. Based on this, in this study, conclusions were drawn by analyzing data derived from written tests and interview results to meet the research focus. The initial conclusions obtained are temporary if the data used at the data collection stage is not robust, so carry out data collection until it is by the desired data. Initial conclusions that are equipped with valid and consistent evidence make the conclusions presented in writing credible.

\section{FINDINGS AND DISCUSSION}

The data in this study are the subject's answers and the results of in-depth interviews. Of the 12 research subjects produced three categories of completion. The category consists of 3 subjects, 7 subjects, and 2 subjects. The first category or type is the coherent and most systematic type and is by mathematical concepts. Subjects of this type decompose by simplifying complex problems into more straightforward problems by sketching each square measure. The abstraction is done; namely, the subject knows the value of the nth term at any value of $n$. This is by the results of the interview, namely:

$R:$ If the size of the square is 10 , how many squares are formed??

$S$ : yeah.... The sum of one square plus 2 squared plus 3 squared and so on is added to ten squared.

This first type of subject tends to complete step-by-step coherently and write it down clearly. Subjects of this type can write the general form of the sequence and even mention the name of the sequence, namely the sequence "square of natural numbers". The general form written is the sum of all squares if the size $\mathrm{n}$ is $\frac{1}{6} n(n+1)(2 n+1)$. The algorithm that appears is that the subject determines all squares starting from a square with 1 unit to 5 units. From there, the issue found a sequence pattern, namely a sequence of squares of natural numbers. After seeing the design, the subject determines the number of squares according to the questions in the problem. From here, the subject of this type is very coherent in working and systematic. The subject prioritizes the substance of the process. The subject also understands the mathematical concept of what he wrote. After completing the work, the subject evaluates his work by rechecking the calculations he did. This process is called debugging. The scan of the answer for the first type of subject can be seen in figure 2 . 


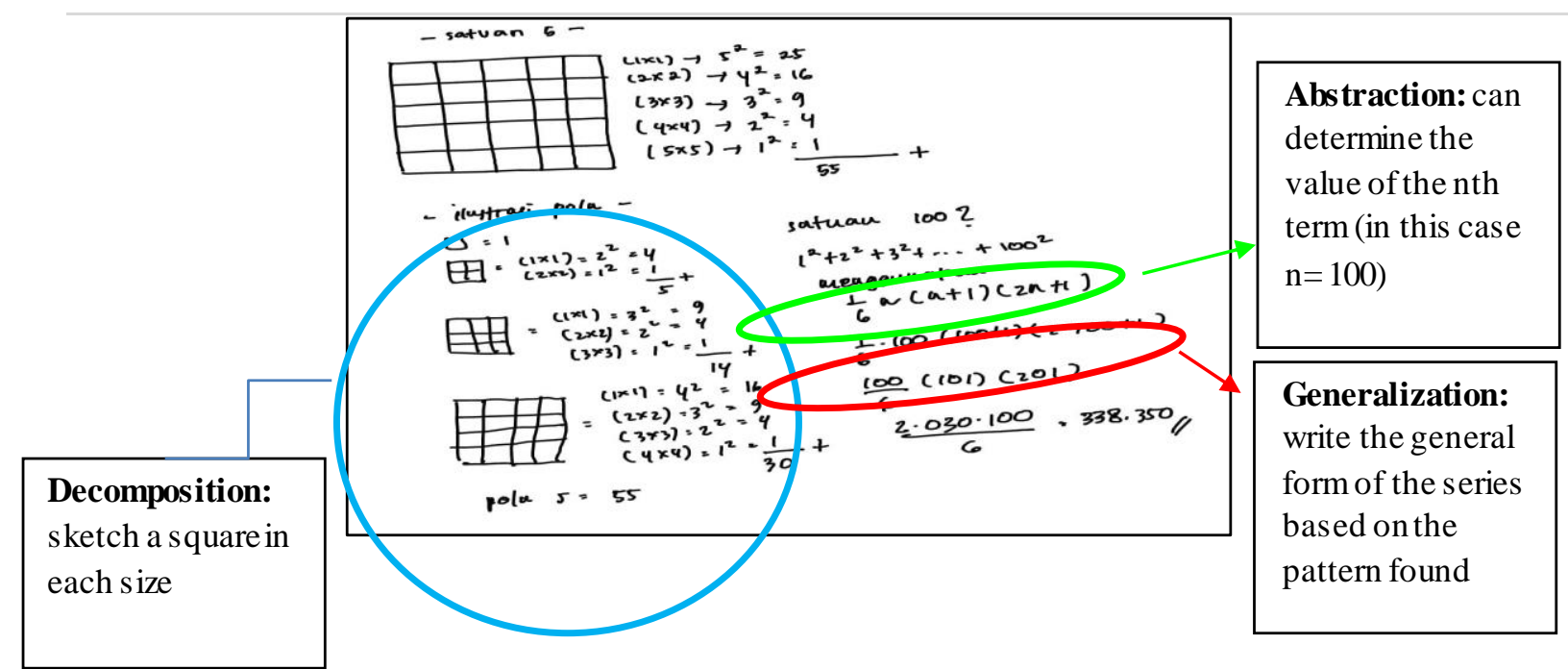

Figure 2. The Answer of Subject First Type

The second type of subject is 7 students. Subjects of this type tend to calculate manually from the values of the nth term. The decomposition carried out by this type of subject is different from the previous type of subject; namely, it does not sketch a square on each square size starting from a 1 unit square to a 5 unit square, but only determines the number of squares in each square size. This subject can state the value of the number of squares in a specific size, but must go through a very long process if the size of the square in question is more than 10 units in size. This is by the following interview results.

$R$ : how many squares if the size is 3 ?

$S:$ ehmmm, ,, $1+4+9$ mom.

$R$ : how many squares if the size is 6 ?

$S:$ yeah...1+4+9+16+25+36 mom

$R$ : okay, then how many squares if the size is 20 ?

$S:$ hmmm (scratching head).... Yes, the series continues until the 2oth term, ma'am.. If I count, the process is long, ma'am, here I can only mention up to 10 units, ma'am.

$R:$ Why?

$S$ : Yes, because I have to calculate manually, ma'am, moreover, the difference is not the same. The difference of each term is a sequence of odd numbers starting from $3 \mathrm{bu}$.

$R$ : Is there no other easier way??

$S$ : hehe, there seems to be a ma'am, but I don't know. If I do the manual calculation, ma'am.

The work process carried out by this type of subject is classified as coherent but not systematic because it tends to calculate manually, which wastes a lot of time and energy. This type of subject makes generalizations but is unable to write them down. Because based on the results of the interview, the subject was able to find a pattern. The algorithm used is to determine the value of each term, identify the difference from the sequence, which then finds the sequence pattern. This type of subject performs debugging by rechecking the results of the work. CT performed by the 
second type of subject tends to be minimal and requires a longer processing time than the first type. Subjects of this type tend to solve manually by writing numbers without symbols. The most important thing for this subject is that the work results in nominal results, not symbols. The following are the results of the work of the second type of subject

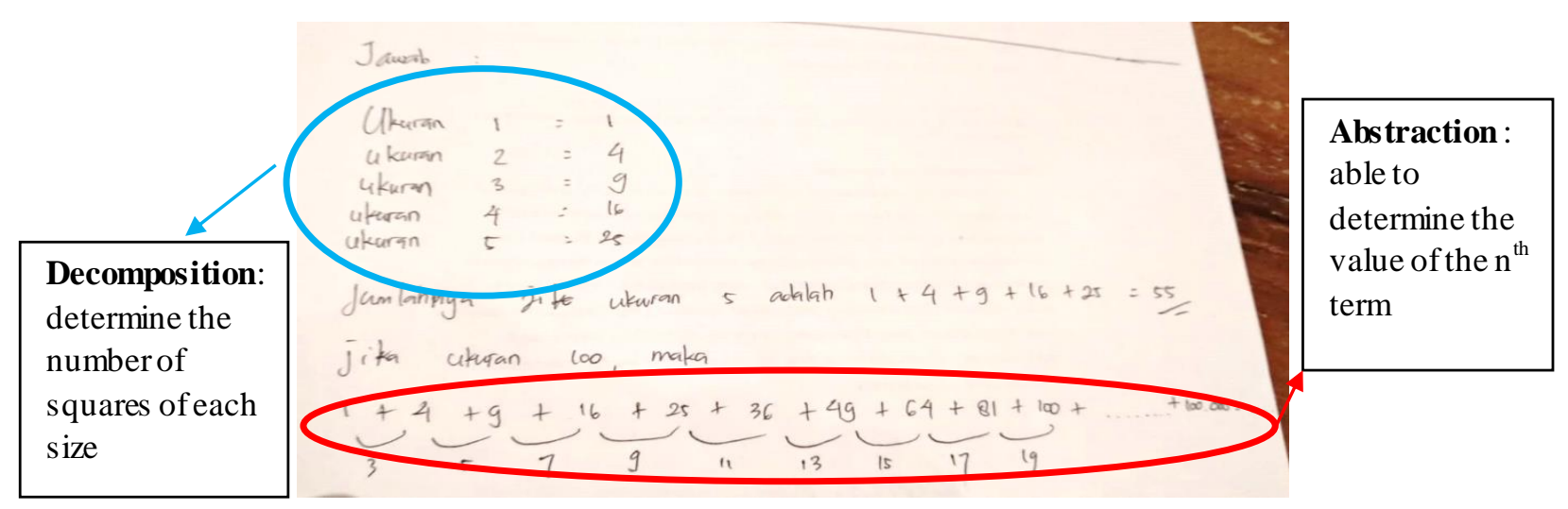

Figure 3. The Answer of Subject Second Type

The third type of subject consists of 2 students. Issues of this type tend to solve problems based on the procedures they have done. Decomposition is done by sketching each square size along with the number of squares. This is the same as that of the first type of subject. Subjects of this type also understand the formed sequence and can determine the value of the nth term (abstraction). Subjects can find patterns of sequences and series and can write them in a general form. The process carried out by this subject is the generalization stage. The work on this type of subject tends to be coherent and systematic, but the substance of the answers is still lacking. The procedure for this type of work is straightforward, as explained by the teacher (educator). First, the subject determines the value of the sum of each square but does not write down the sequence of its small parts and only directly writes the number. Based on the pictures made, the subject can find the patterns that are formed. The subject realizes and understands that the series found is a series of multilevel numbers. This means that the difference is found at the second level. From here, the subject remembers the working procedure if he finds a question like this, namely the issue assumes that $U_{n}=a n^{2}+b n+c$ where $a$ is the first term, and the subject determines the values of $b$ and $c$. Here the subject relies on his memory on the working procedure alone, does not recheck whether the steps he has taken are appropriate or not. Debugging that is done is to make a writing error and have fixed it.

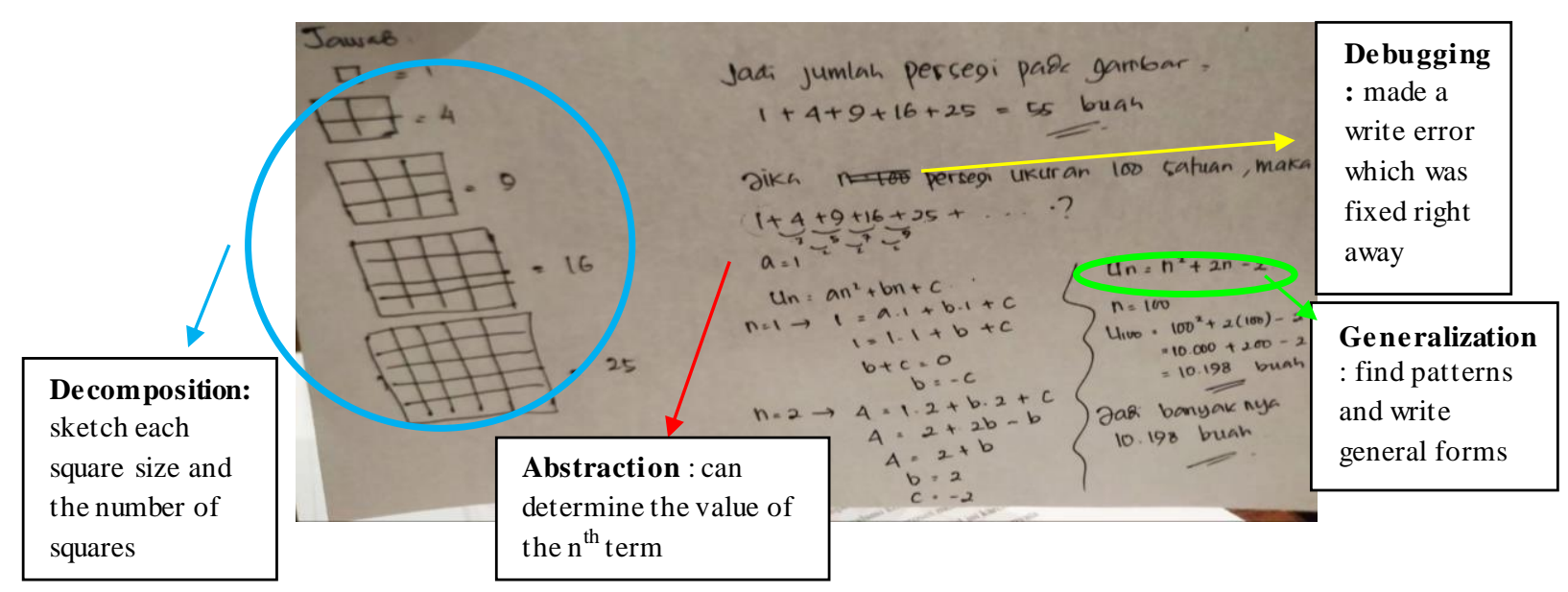

Figure 4. The Answer of Subject Third Type 
Subjects of the first type solve problems coherently and systematically. Subjects tend to perform CT in the order of decomposition - abstraction - generalization - algorithmic debugging. The first type of subject performs decomposition, breaking down complex problems into simpler problems by sketching squares ranging from 1 unit to 5 units in size. The subject also writes down the number of squares that can be made in each of these sizes in detail and clearly. This is done to facilitate the work and understanding in solving problems. In addition, the decomposition results make the subject able to find the pattern of the line. According to the opinion of Kashefi, Alias, Kahar, Buhari, \& Zakaria (2015), complex problems in mathematics can be solved by visualization. When doing decomposition, the subject of the first type draws or sketches as a tool or a way to decompose complex problems into simpler ones. This is done because visualizing the problem is a powerful strategy for solving problems representing an abstract version of the mathematical language (Garderen, 2006; Lavy, 2007). In addition, diagrams or pictures that students build to improve their understanding will automatically produce a big shot in their minds to explore solutions to problems (Deliyianni, Monoyiou, Elia, Georgiou, \& Zannettou, 2009; Rösken \& Rolka, 2006).

The abstraction of the first type of subject is complete. It can be seen from the answers' speed, fluency, and accuracy when answering the number of values of the nth term with any value of $n$. From this, it can be seen that the subject of the first type has correctly understood ideas, concepts and their relationships (Mitchelmore \& White, 2007). In addition, the subjects also used mathematical symbols that they made themselves to be used as a benchmark or key to determining the value of any term. This is by Van Oers (2010) opinion, which says that abstraction is a dialectical process between the object, expressly given, and its abstract representation. Abstraction can be described by focusing on the configuration of mental models, which can be expressed as conceptual, symbolic models.

Generalization is made by doing iterations to find patterns and write general forms. In the first type of subject, abstraction begins by describing the problem to find the relationship or relationship of each object (relating). Then perform calculations (searching) in iterations to find the pattern formed and finally write down the general structure (extending) to determine the solution. This generalization belongs to the conception of action (Ellis, 2007). The generalization strategy used by the first type of subject is functional. This is in line with Amit \& Neria (2008), which states that the operational system used by students when generalizing can make students find the nth termin a sequence.

The algorithmic is carried out coherently, namely representing mathematical ideas with pictures to facilitate work. The findings obtained are represented by writing them on the answer sheet with symbols. The problem is described clearly to get the general pattern and form of the sequence. The representation made is visual, namely with pictures. The images created will be a bridge in carrying out ideas in solving problems. As stated by Boonen, Van Wesel, Jolles, \& Van der Schoot (2014); van Garderen \& Montague (2003); van Garderen, Scheuermann, Poch, \& Murray (2018), that visual representation can develop knowledge and skills in solving mathematical problems. In addition, subjects in the substantial routine type also represent findings into mathematical symbols. The algorithm built by this type of subject is to find a mathematical idea from the image he made, then perform iterations or calculations to find a relationship to form a pattern. The pattern formed will be represented in mathematical symbols and is called the general form. This type of subject uses conceptual knowledge combined with procedural knowledge.

Procedural knowledge is used when iterating to find a pattern. According to Lockwood \& Asay (2016), one of the characteristics of CT is the use of procedural steps to achieve a specific goal or solve a problem to get a solution. An algorithm here is one of one's strategies in solving mathematical problems. Academically successful students use effective strategies in issue solving and have acquired their perceptions (Garrett, Mazzocco, \& Baker, 2006; Kaya, Izgiol, \& Kesan, 
2014). Debugging is carried out by the subject by rechecking the answers. As in problem-solving theory, there are stages or steps to solving problems, namely "evaluating". According to Reiss \& Törner (2007), one of the problem-solving steps is to check each part of the solution and make sure it is correct.

Subjects of the second type tend to solve problems by writing numbers or nominals, not in the form of symbols. The steps for completing this type of subject are incomplete, and they are still lacking. Decomposition is done by writing down the number of squares in each size ranging from 1 unit to 5 units, but this type of subject does not make a sketch. The subject can determine the nth term of the sequence in the problem but is limited to $n=10$. This is because this type of subject determines the value of each term manually. The subject's understanding of the number syllable material is still low. In this case, the subject does not perform mathematical representations to explore his knowledge, bringing up new ideas in solving problems. Mathematical graphics play an essential role in developing patterns and structures (Mulligan, Kemp, \& Highfield, 2008).

The subject's limitations in determining the value of the sequence $n>10$ resulted in the subject not writing down the general form of the sequence or series referred to in the problem. Actually, in this case, the subject can find the pattern of the sequence, but the subject cannot express it into a mathematical model. This is because the subject does not visualize the problem, so there are no new ideas in the process. Subjects tend to be fixated on the results in the form of numbers or nominal. The reason is that generalizations based on visual patterns allow students to make conceptual constructions of mathematical objects and concepts (Rivera \& Becker, 2008). It is easier to give meaning to symbols and expressions (Barbosa \& Vale, 2015).

In this second type of subject, the completion steps are concise and less detailed. Subjects tend to calculate the value of each term of the sequence. Subjects represent their mathematical ideas in the form of numbers and not in the form of visual images or symbols. The reason is, to change the patterns found into algebraic forms, students cannot rely on guessing and testing strategies; Algebraic activities must be based on finding similarities and forming general concepts followed by the formation of generalization expressions (Amit \& Neria, 2008; Radford, 2006).

The third type of subject tends to be similar in characteristics to the first type of subject. Issues of this type also perform decomposition by sketching and determining the number of squares in each size. However, this third type of subject only uses their procedural knowledge without using their conceptual understanding. This resulted in the issue being unable to write down the solution correctly. Issues of this type tend not to double-check their answers.

\section{CONCLUSION}

Based on the research results and supporting theories, it can be concluded that the CT of prospective mathematics teacher students in solving patterned geometry problems can be grouped into three types, namely substantial CT, nominal CT, and procedural CT. Prospective mathematics teacher students who solve patterned geometry problems using conceptual knowledge combined with procedural knowledge, perform mathematical iterations, find patterns and can express them into mathematical models are called substantial CT type students. Prospective mathematics teacher students who solve patterned geometry problems by counting numbers without using symbols are called nominal CT type students. Meanwhile, prospective mathematics teacher students who solve patterned geometry problems using only procedural knowledge, do not master the concepts, and only follow the steps taught from their previous learning outcomes are called procedural CT type students. 


\section{REFERENCES}

Amit, M., \& Neria, D. (2008). "'Rising to the challenge"': Using generalization in pattern problems to unearth the algebraic skills of talented pre-algebra students. ZDM - International Journal on Mathematics Education, 4O(1), 111-129. https://doi.org/10.1007/s11858-007-0069-5

Angeli, C., Voogt, J., Fluck, A., Webb, M., Cox, M., Malyn-Smith, J., \& Zagami, J. (2016). A K-6 Computational Thinking Curriculum Framework: Implications for Teacher Knowledge. Educational Technology \& Society, 19(3), 47-57.

Ansori, M. (2020). Pemikiran Komputasi (Computational Thinking) dalam Pemecahan Masalah. Dirasah : Jurnal Studi Ilmu Dan Manajemen Pendidikan Islam, 3(1), 111-126. https://doi.org/10.29062/dirasah.v3i1.83

Astuti, E. P. (2017). Representasi Matematis Mahasiswa Calon Guru dalam Menyelesaikan Masalah Matematika. Beta Jurnal Tadris Matematika, 1o(1), 70. https://doi.org/10.20414/betajtm.v10i1.100

Aziz, L. A. (2021). Analisis Kemampuan Computational Thinking Mahasiswa Dalam Menyelesaikan Masalah Matematika. Jurnal Undikma, 9(1), 34-42.

Barbosa, A., \& Vale, I. (2015). Visualization in pattern generalization :Potential and Challenges. Journal of the European Teacher Education Network, 10(1), 57-70.

Bobango, J. . (1993). Geometry for All Student: Phase-Based Instruction. Dalam Cuevas (Eds). Reaching All Students With Mathematics. Virginia:The National Council of Teachers of Mathematics,Inc.

Boonen, A. J. H., Van Wesel, F., Jolles, J., \& Van der Schoot, M. (2014). The role of visual representation type, spatial ability, and reading comprehension in word problem solving: An item-level analysis in elementary school children. International Journal of Educational Research, 68, 15-26. https://doi.org/10.1016/j.ijer.2014.08.001

Deliyianni, E., Monoyiou, A., Elia, I., Georgiou, C., \&Zannettou, E. (2009). 'Pupils'visual representations in standard and problematic problem solving in mathematics: Their role in the breach of the didactical contract. European Early Childhood Education Research Journal, 17(1), 95-110. https://doi.org/10.1080/13502930802689079

Ellis, A. B. (2007). Connections between generalizing and justifying: 'Students' reasoning with linear relationships. Jourmal for Research in Mathematics Education, 38(3), 194-229. https://doi.org/10.2307/30034866

Erdogan, T., Akkaya, R., \& Çelebi Akkaya, S. (2009). The effect of the Van Hiele model based instruction on the creative thinking levels of 6 th grade primary school students. Kuramve Uygulamada Egitim Bilimleri, 9(1), 181-194.

Garderen, D. Van. (2006). Spatial Visualization, Visual Imagery, and Mathematical Problem Solving of Students With Varying Abilities. JOURNAL OF LEARNING DISABILITIES, 39(6), 496-506.

Garrett, A. J., Mazzocco, M. M. M., \& Baker, L. (2006). Development of the Metacognitive Skills of Prediction and Evaluation in Children With or Without Math Disability. Learning Disabilities Research and Practice, 21(2), 77-88. https://doi.org/10.1111/j.1540-5826.2006.00208.x

Hendriana, H., Sumarmo, U., \& Rohaeti, E. E. (2013). Kemampuan Komunikasi Matematik Serta Kemampuan dan Disposisi Berpikir Kritis Matematis. Jurnal Matematika Dan Pendidikan Matematika, 2(1), 35-45.

Imswatama, A., \& Muhassanah, N. (2016). Analisis Kesalahan Mahasiswa Dalam Menyelesaikan Soal Geometri Analitik Bidang Materi Garis Dan Lingkaran. Suska Journal of Mathematics Education, 2(1), 1. https://doi.org/10.24014/sjme.v2i1.1368

Kashefi, H., Alias, N. A., Kahar, M. F., Buhari, O., \& Zakaria, S. (2015). zVisualization in mathematics problem solving meta-analysis research. E-Proceeding of the International Conference on Social Science Research, 2015(June 2015), 803-812. Retrieved from 
http://worldconferences.net

Kawuri, K. R., Budiharti, R., \& Fauzi, A. (2019). Penerapan Computational Thinking untuk Meningkatkan Kemampuan Berpikir Kritis Siswa Kelas X MIA 9 SMA Negeri 1 Surakarta pada Materi Usaha dan Energi 6. Jurnal Materi Dan Pembelajaran Fisika (JMPF), 9(2), 116-121.

Kaya, D., Izgiol, D., \& Kesan, C. (2014). The investigation of elementary mathematics teacher 'candidates' problem solving skills according to various variables. International Electronic Journal of Elementary Education, 6(2), 295-313.

Lavy, I. (2007). A case study of dynamic visualization and problem solving. International Journal of Mathematical Education in Science and Technology, 38(8), 1075-1092. https://doi.org/10.1080/00207390601129196

Lockwood, E., \& Asay, A. (2016). Algorithmic thinking : An initial characterization of computational thinking in mathematics. The Annual Meeting of the North American Chapter of the International Group for the Psychology of Mathematics Education (38th, Tucson, AZ, Nov 3-6, 2016), (November).

Masfingatin, T., \& Maharani, S. (2019). Computational Thinking : Students On Proving Geometry Theorem. International Journal of Scientific \& Technology Research, 8(09), 2216-2223.

Meha, A. M., \& Bullu, N. I. (2021). Hubungan Kesiapan Mengajar Dan Proses Praktik Pengalaman Lapangan Dengan Keterampilan Dasar Mengajar Mahasiswa Pendidikan Biologi. Edukatif : Jurnal Ilmu Pendidikan, 3(2), 412-420. https://doi.org/10.31004/edukatif.v3i2.323

Mitchelmore, M., \& White, P. (2007). Abstraction in Mathematics Learning The foundational work on hierarchical abstraction theory was done by the late. Mathematics Education Research Journal, 19(2), 1-9.

Mulligan, J., Kemp, C. R., \& Highfield, K. (2008). Encouraging Mathematical Thinking through Pattern \& Structure: An Intervention in the First Year of Schooling. Australian Primary Mathematics Classroom (APMC), 3(January), 10-15.

Nurfalah, A., \& Bernard, M. (2020). Analisis Kesalahan Siswa SMK dalam Menyelesaikan Soal Materi Geometri Dimensi Tiga. Maju, 7(1), 70-75.

Pasandaran, R. F., \& Mufidah, M. (2020). Studi Kasus Pembelajaran Geometri Analitik. Pedagogy: Jurnal Pendidikan Matematika, 5(2), 91-105. https://doi.org/10.30605/pedagogy.v5i2.413

Radford, L. (2006). Algebraic Thinking and The Generalization of Patterns: A Semiotic Perspective. Proceedings of the 28th Annual Meeting of the North American Chapter of the International Groupfor the Psychology of Mathematics Education, 1-20. https://doi.org/10.5840/jphil20019858

Reflina. (2020). Kesulitan mahasiswa calon guru matematika dalam menyelesaikan soal pembuktian matematis pada mata kuliah geometri. Jurnal Analisa, 6(1), 80-90.

Reiss, K., \& Törner, G. (2007). Problem solving in the mathematics classroom: The German perspective. ZDM - International Jourmal on Mathematics Education, 39(5-6), 431-441. https://doi.org/10.1007/s11858-007-0040-5

Rivera, F. D., \& Becker, J. R. (2008). Middle school 'children's cognitive perceptions of constructive and deconstructive generalizations involving linear figural patterns. ZDM International Journal on Mathematics Education, 4O(1), 65-82. https://doi.org/10.1007/s11858-007-0062-z

Rösken, B., \& Rolka, K. (2006). A picture is worth a 1000 words - The role of zvisualization in mathematics learning. Proceedings of the 3oth Conference of the International Group for the Psychology of Mathematics Education, 4(1989), 457-464.

Selby, C. (2013). Computational Thinking :The Developing Definition. ITiCSE Conference 2013,58.

Sengupta, P., Dickes, A., \& Farris, A. (2018). Toward a Phenomenology of Computational Thinking in K-12 STEM. In Computational Thinking in STEM Discipline: Foundations and Research 
Highlights. Springer.

Sudarsono, Mikrayanti, \& Murtalib. (2017). Peningkatan Kemampuan Pemahaman dan Pemecahanmasalah Geometri Siswa SMA Melalui Transactional Reading Strategy. Jurnal Pendidikan MIPA, 7(1), 61-74.

Sugiyono, Murdanu, \& Murdiyani, N. M. (2014). Pengembangan Perangkat Pembelajaran Matematika Pada Topik Geometri Menggunakan Paradigma Baru Dalam Pembelajaran Matematika. Jurnal Pendidikan Matematika Dan Sains Tahun II, 2(2), 117-125.

van Garderen, D., \& Montague, M. (2003). Visual-Spatial Representation, Mathematical Problem Solving, and Students of Varying Abilities. Learning Disabilities Research and Practice, 18(4), 246-254.https://doi.org/10.1111/1540-5826.00079

van Garderen, D., Scheuermann, A., Poch, A., \& Murray, M. M. (2018). Visual Representation in Mathematics: Special Education Teachers' Knowledge and Emphasis for Instruction. Teacher Education and Special Education, 41 (1), 7-23. https://doi.org/10.1177/0888406416665448

van Oers, B. (2010). Emergent mathematical thinking in the context of play. Educational Studies in Mathematics, 74(1), 23-37.https://doi.org/10.1007/s10649-009-9225-x

Wing, J. M. (2008). Computational thinking and thinking about computing. Philosophical Transactions of the Royal Society A: Mathematical, Physical and Engineering Sciences, 366(1881), 3717-3725. https://doi.org/10.1098/rsta.2008.0118

Wing, J. M. (2011). Computational thinking. Communications of the ACM, 3-3. https://doi.org/10.1109/vlhcc.2011.6070404

Yanty Putri Nasution, E. (2017). Meningkatkan Kemampuan Spasial Siswa Melalui Pembelajaran Geometri Berbantuan Cabri 3D. M A T H L I N E : Jurnal Matematika Dan Pendidikan Matematika,2(2), 179-194. https://doi.org/10.31943/mathline.v2i2.45

Yuniarti, Y. (2014). Pengembangan Kemampuan Komunikasi Matematis Dalam Pembelajaran Matematika Di Sekolah Dasar.EduHumaniora | Jurnal Pendidikan Dasar Kampus Cibiru, 6(2), 109-114. https://doi.org/10.17509/eh.v6i2.4575

$\mathrm{Zhu}, \mathrm{Z}$. (2007). Gender differences in mathematical problem-solving patterns : A review of the literature. Interbational Education Journal, 8(2), 187-203. 